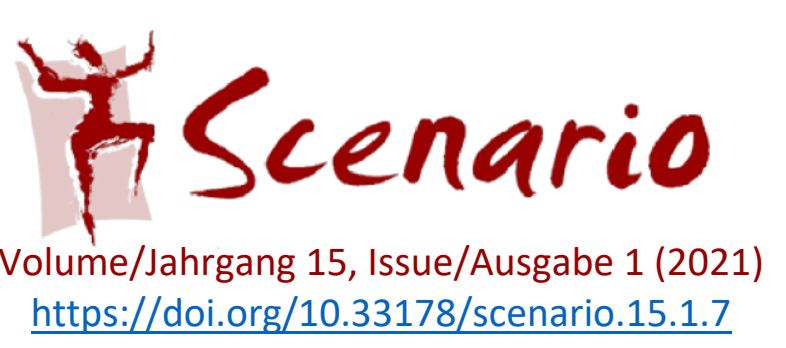

\title{
Review: Köhler, J. (2017). Theatrale Wege in der Lehrer/innenbildung. Theaterpädagogische Theorie und Praxis in der Ausbildung von Lehramtsstudierenden. Kopäd.
}

John Crutchfield

The views and opinions expressed in the book reviews are those of the authors and do not necessarily reflect the position of SCENARIO.

It has been several years now since Micha Fleiner (2016) published his painstakingly researched "snapshot" of the state of the performing arts in foreign language teacher-training. Although that work focused primarily on French Education programs in the German university system, it provided a much-needed empirical basis for assessing the general progress of a performance-based FL didactics. The result was ernüchternd, as the Germans would say: "sobering". In many programs, drama- and theater-based approaches continued to represent a relatively marginal and heterogeneously-conceived phenomenon (Fleiner, 2016, p. 295) that at most might prove useful as a pedagogical implement, i.e. as a tool to be deployed from time to time in order to spice things up in the language classroom. There is perhaps no harm in this view, but it is a far cry from what Manfred Schewe means by a performative teaching and learning culture (Schewe, 2013), in which performance is not a tool but a fundamental approach to the use of tools per se. In such a culture, teaching is rightly seen as a craft - a performative craft - and the aim of teacher education is craftsmanship. But such a culture, if it is to come about, depends upon teachers being adequately trained in performance - a form of creative co-presence that, in one way or another, lies at the basis of all good teaching.

But the question has been: Where do we begin? Who will train such future teacher-artists if not another teacher-artist, someone who has not only mastered the craft of performance but who also understands its translation into the pedagogical situation of the classroom? And where shall such a teacher-artist be found? Wouldn't that person's existence depend upon the very teaching and learning culture they are tasked with creating in the first place? And thus we seem to be caught in that famously vicious hermeneutic problem of the chicken and the egg. 
Julia Köhler, the author of Theatrale Wege in der Lehrer/innenbildung. Theaterpädagogische Theorie und Praxis in der Ausbildung von Lehramtsstudierenden, embodies one kind of solution, and her example is compelling. A trained actor with over twenty years of professional experience, Köhler has been active since 2008 at the Centre for Teacher Education at the University of Vienna, where she teaches (among other things) Theaterpädagogik, a term we might roughly translate as Theater Education. The work presently under discussion is Köhler's 2016 doctoral dissertation, in which she investigates the potential advantages of a theatrical approach to teacher training in general, of a theatrical pedagogy in particular, and of a deeper anchoring of Theater as a specific subject in school curricula. These are the three theatrale Wege ("theatrical paths") of the book's title.

It is no accident that these are also the three dimensions Florian Vaßen (2016) addresses in his essay on "The Diversity of Theaterpädagogik in the German Schools". But where Vaßen offers a brief sketch, Köhler lays out a solid theoretical basis and justification, drawing on what she sees as the two primary "source disciplines" for Theaterpädagogik. These are Theater Science (Theaterwissenschaft) and Education Science (Erziehungswissenschaft). Much of this material (Köhler devotes the first hundred pages or so to this genealogical and theoretical groundwork) will seem rather technical to non-specialist readers. Nevertheless, Köhler offers a powerful synthesis of theory and practice, and although foreign and second-language didactics receives only indirect treatment here, the book invites a number of useful reflections for anyone interested in promoting a performative FL teaching and learning culture.

Granted, Köhler does not make much explicit use of the concept of performativity, and the word performative rarely appears in the book. (Unfortunately, the book lacks an index that would provide more precise information.) This is due at least in part to the fact that Köhler is working primarily within the conceptual framework of Theaterwissenschaft, a discipline that pre-exists both the hybrid discipline of Theaterpädagogik and the general performative turn of the 1960's, and that has its own way of understanding the nature of performance. This understanding - codified in the term Theatralität ("theatricality") - is somewhat more restricted in its use than the terms "performativity," "performative" and "performance" as these have come to be used in the pages of this journal. But Köhler's contention (and this is where her work dovetails with that of Manfred Schewe and of various other contributors to SCENARIO) is that the approaches developed within that specific area actually have a much wider application, namely, to teacher training in general. This becomes clear as soon as one recognizes the performative dimension of teaching as such. In Vaßen's words, "Classroom teaching is a performative event." (Vaßen, 2016, p. 245)

The book offers three primary theses: 1) Theatrical experiences and training ought to be integrated into teacher education programs from the very beginning, in order to have time to 
bed-in and strengthen into pedagogical/professional habits; 2) Theatrical teaching and learning processes promote not only those competencies relevant for the individual school subjects, but also overarching (überfachliche) competencies; 3) The artistic discipline of Theater itself, when placed on equal footing with the other academic subjects, contributes significantly to the general educational mission of school.

While the third point will be of interest primarily to Theater teachers themselves (if not to administrators and policy-makers), the second point might be considered an article of faith for readers of this journal. In any event, as a perusal, for example, of the neuroscientific research of Manfred Spitzer, Markus Kiefer and others makes clear, it is now a well-researched and generally accepted scientific fact. Therefore let us consider the first point: a "theatrical" approach to teacher training, regardless of subject. Here Köhler uses the concept of a "professional habitus," where she locates a complex of professional pedagogical competencies (p. 112) that any teacher should possess. Drawing on the EPIK Domain Concept (Entwicklung von Professionalität im International Kontext), she lists Professionsbewusstsein ("Professional Awareness"), Reflexions- und Diskursfähigkeit ("Capacity for Reflection and Discourse"), Differenzfähigkeit ("Capacity for Difference"), Kooperation und Kollegialität ("Cooperation and Collegiality") and Personal Mastery, which she describes as "areas of action, in which abilities and skills as well as attitudes bear fruit." (p. 113)

This point is an implicit acknowledgement of the idea of teaching-as-craft ${ }^{1}$. Like any craft, teaching is embodied, and depends to a profound degree on the development of certain embodied habits. (A teacher, like an actor, for example, must have been trained to sense without thinking - the dimensions and specific relational, haptic, olfactory and acoustic qualities of the physical space in which they are working, or to intuit clearly and in real time something as subtle as the quality of attention in the room.) But the habits Köhler points to are more correctly described as habits of mind - or what we might call the ethical dimension of teaching. Such attitudes and behaviors are also, as Köhler reminds us, not only trainable but in need of training, long before a young teacher steps into their first job.

As Köhler goes on to show, an explicitly theatrical (read: performative) training in the context of general teacher education offers an effective framework for addressing these five domains, and hence (as she argues) ought to be embedded in teacher training from the very beginning:

The integration of theater-pedagogical elements in the fundamental education of teachers - and the resulting benefits for one's approach to pedagogical professionalism, to a transformation of one's own image of the profession and of one's basic understanding of didactics, and to an

\footnotetext{
${ }^{1}$ For more on the idea of teaching-as-craft, see Crutchfield (2019).
} 
expansion of one's methodological repertoire in all school subjects - all of this is worth striving for. (p. 202-203)

So let's imagine we have Julia Köhler herself - a trained theater artist and an experienced teacher - to design and implement a "theatrical" curriculum for our Education students. What would such a curriculum look like? Here too, Köhler does not disappoint. Drawing on the work of a "Teacher Education" task force established as part of the Federal Association "Theater in der Schule," Köhler proposes a schema that offers modules in "Theater-Pedagogy for the Development of the Teacher Personality," "Theater-Pedagogy in Diverse Learning Situations," and "Theater-Pedagogy and Subject Instruction."

An examination of the details of this proposal makes clear that Köhler's understanding of Theaterpädagogik bears a strong resemblance to what we might, without too much procrustean stretching, call performative pedagogy; and drawing on the solid theoretical sources of Theaterwissenschaft on the one hand and Erziehungswissenschaft on the other, she makes a strong case for creating a performative teaching and learning culture.

Nor is this surprising. To the degree that the performative approach in education draws inspiration from the performing arts, it makes sense for teachers to engage not only with what the artists themselves say about their art, but what the scholars say about it. After all, as can clearly be seen in the pages of this journal, practice, theory and research are inextricable from each other. Every practice implies a theory, which in turn guides research and ultimately impacts practice. Thus while the theoretical work of theater-scientists like, for example, Erika Fischer-Lichte or Andreas Kotte can seem almost Kantian in its conceptual hair-splitting, it behooves us every now and then to "look up from the dish" of our own more immediate disciplinary concerns and to consider what is being said and thought and debated elsewhere at the table. The terminology may be different and at times confusing, but we may find - as this reviewer does in Julia Köhler's book - that the insights are both useful and (perhaps more importantly) encouraging.

\section{Bibliography}

Crutchfield, J. (2019). The Teaching Lab: An immodest proposal. In S. Even, D. Miladinović \& B.

Schmenk (Eds.), Lernbewegungen inszenieren: Performative Zugänge in der Sprach-, Literatur- und Kulturdidaktik. Festschrift für Manfred Schewe zum 65. Geburtstag (pp. 33-43). Narr Francke Attempto.

Fleiner, M. (2016). Performancekünste im Hochschulstudium: Transversale Sprach-, Literatur- und Kulturerfahrungen in der fremdsprachlichen Lehrerbildung (Edition SCENARIO Vol. II). SchibriVerlag. 
Crutchfield: Rezension von Theatrale Wege in der Lehrer/innenbildung

Kiefer, M. (2018). Verkörperte Kognition: Die Verankerung von Denken und Sprache in Wahrnehmungs- und Handlungserfahrung. In H. Böttger and M. Sambanis (Eds.), Focus on Evidence: Netzwerke zwischen Fremdsprachendidaktik und Neurowissenschaften (pp. 31-44). Narr Francke Attempto.

Schewe, M. (2013). Taking stock and looking ahead: Drama pedagogy as a gateway to a performative teaching and learning culture. Scenario, 7(1), 5-23. https://doi.org/10.33178/scenario.7.1.2

Spitzer, M. (2002). Lernen: Gehirnforschung und die Schule des Lebens. Spektrum.

Vaßen, F. (2016). The diversity of Theaterpädagogik in German Schools - Theater and theatrical training in the context of teacher education, as a method of instruction, and as an artistic/aesthetic school subject (J. Crutchfield, Trans.). In S. Even \& M. Schewe (Eds.), Performatives Lehren, Lernen, Forschen. Performative Teaching, Learning, Research (Edition SCENARIO Vol. III, pp. 241-279). Schibri-Verlag. 


\title{
Rezension: Köhler, J. (2017). Theatrale Wege in der Lehrer/innenbildung. Theaterpädagogische Theorie und Praxis in der Ausbildung von Lehramtsstudierenden. Kopäd.
}

\author{
John Crutchfield, übersetzt von Dragan Miladinović
}

Die in Buchrezensionen vertretenen Ansichten und Meinungen sind die der jeweiligen Rezensent:innen und reflektieren nicht notwendigerweise die Position von SCENARIO.

Es ist nun ein paar Jahre her, dass Micha Fleiner (2016) seine akribische Studie zum Status quo der performativen Künste in der Fremdsprachenlehrendenbildung veröffentlicht hat. Obwohl sich seine Arbeit hauptsächlich den Lehramtsstudiengängen Französisch an Universitäten im amtlich deutschsprachigen Raum widmet, bietet sie eine wichtige empirische Basis zur Einschätzung des allgemeinen Fortschritts von performativen Zugängen in der Fremdsprachenforschung. Fleiners Fazit ist ernüchternd, denn wie seine Studie zeigt, fristet drama- und theaterbasierte Lehre in vielen Studiengängen noch immer ein Dasein als ein „randständiges und heterogen konzipiertes Lehr-Lern-Phänomen“ (Fleiner, 2016, S. 295), das sich höchstens als pädagogisch hilfreiches Tool erweise und von Zeit zu Zeit eingesetzt werde, um etwas Pepp in den Sprachunterricht zu bringen. Nun schadet das zwar nicht, allerdings ist es weit davon entfernt, was Manfred Schewe unter einer performativen Lehr- und Lernkultur (Schewe, 2013) versteht, indem Performance nicht lediglich als Werkzeug, sondern als umfassender Ansatz verstanden wird. In einer solchen Kultur wird Lehren zu Recht als performatives Handwerk verstanden und das Ziel der Lehrausbildung daher als Handwerkskunst. Solch eine Kultur erfordert allerdings auch, dass Lehrende adäquat in Performance geschult werden, die hier verstanden wird als eine Form kreativer Kopräsenz, die gewissermaßen der Grundstein aller guten Lehre ist.

Aber wo sollten wir beginnen? Wer wird zukünftige Lehr-Künstler:innen ausbilden, wenn nicht Lehr-Künstler:innen, d.h., Menschen, die nicht nur die Kunst der Performance beherrschen, sondern auch verstehen, wie sie in pädagogischen Settings der Klassenräume um- und übersetzt werden kann? Und wo lassen sich solche Lehr-Künstler:innen finden? Würde die Existenz dieser Personen nicht von gerade jener Lehr- und Lernkultur abhängen, die diese Personen eigentlich herstellen sollte? Es scheint, als wären wir in der Metapher des Henne-EiProblems gefangen.

Julia Köhler, die Autorin von Theatrale Wege in der Lehrer/innenbildung. Theaterpädagogische Theorie und Praxis in der Ausbildung von Lehramtsstudierenden, verkörpert gewissermaßen 
einen Lösungsansatz, und überzeugt damit auf ganzer Linie: Als ausgebildete Schauspielerin mit über 20 Jahren professioneller Erfahrung ist Köhler seit 2008 am Zentrum für Lehrer:innenbildung der Universität Wien tätig, wo sie u.a. Theaterpädagogik unterrichtet. Die vorliegende Publikation stellt ihre 2016 abgeschlossene Dissertation dar, in der sie zunächst die potenziellen Vorteile eines theaterbasierten Ansatzes in der Lehrendenbildung im Allgemeinen betrachtet, und dann die einer theaterpädagogischen im Besonderen. Schließlich untersucht sie die Vorteile der tieferen Verankerung von Theater als Schulfach. Genau das sind die drei theatralen Wege, die bereits im Titel angesprochen werden.

Auf diese drei Bereiche geht auch Florian Vaßen (2016) in seinem Aufsatz „Die Vielfalt der Theaterpädagogik in der Schule" ein. Doch wo Vaßen einen kurzen Überblick bietet, liefert Köhler eine detaillierte Auseinandersetzung, für die sich die Autorin auf die zwei Grunddisziplinen der Theaterpädagogik bezieht: Theaterwissenschaft und Erziehungswissenschaft. Ein Großteil des Buches (Köhler widmet die ersten etwa 100 Seiten der Genese ihrer Forschung und theoretischen Grundlage) wird Lai:innen sehr fachspezifisch erscheinen. Nichtsdestotrotz bietet Köhlers Buch eine überzeugende Synthese von Theorie und Praxis. Obwohl Fremd- und Zweitsprachendidaktik nur implizit behandelt wird, liefert das Buch auch denjenigen, die an der (Weiter-)Entwicklung einer performativen Fremdsprachenlehr- und -lernforschung interessiert sind, genügend Denkanstöße.

Allerdings bezieht sich Köhler in ihrem Buch selten explizit auf das Konzept von Performativität und so findet der Begriff performativ kaum Eingang in ihren Text. (Leider fehlt ein Index, der hierfür eine genauere Auskunft bieten würde.) Dies liegt daran, dass sich Köhler hauptsächlich im Rahmen der Theaterwissenschaft bewegt, die sowohl der hybriden Theaterpädagogik als auch dem performativen Turn der 60er vorausgeht. Dem Begriff Performance liegt in der Theaterwissenschaft ein eigenes Verständnis zugrunde, welches im Terminus Theatralität verortet ist. Dieser Begriff ist in gewisser Weise eingeschränkter als beispielsweise Performativität, performativ und Performance, die wiederum in dieser Zeitschrift häufig Verwendung finden. Jedoch besteht Köhlers Argument (und hier liegt der Überschneidungspunkt ihrer Arbeit und jener von Manfred Schewe und vieler anderer Beitragender zu dieser Fachzeitschrift) darin, dass die in diesem Gebiet entwickelten Ansätze eine viel breitere Bedeutung für die Lehrendenbildung haben. Dies wird spätestens dann klar, wenn die performative Dimension des Lehrens erkannt wird. Um es in Vaßens Worten zu fassen: „Unterricht ist ein performatives Ereignis.“ (Vaßen, 2016, S. 90)

Das Buch bietet drei Hauptthesen: 1) Theatrale Arbeit sollte von Anfang an in die Lehrendenbildung integriert werden, sodass sie über einen längeren Zeitraum als Bestandteil des pädagogischen/professionellen Habitus verinnerlicht wird. 2) Theatrales Lehren und Lernen fördert nicht nur die fachlichen Kompetenzen, sondern auch die überfachlichen. 3) Das 
künstlerische Schulfach Theater kann, wenn es auf dieselbe Ebene gestellt wird wie andere Unterrichtsfächer, einen wichtigen Beitrag zur allgemeinbildenden Aufgabe der Schule leisten.

Während der letzte Punkt vor allem für Lehrende des Unterrichtsfachs Theater von Interesse sein wird (und für Entscheidungstragende in der Schulpolitik), stellt der zweite Punkt eine Art Glaubensbekenntnis für Leser:innen dieser Fachzeitschrift dar. Jedenfalls ist dieser Punkt mittlerweile gut erforscht und gilt weitläufig als wissenschaftlich belegt, wie beispielsweise die neurowissenschaftliche Forschung von Manfred Spitzer (2002) und Markus Kiefer (2018) zeigt. Deswegen soll dem ersten Punkt, der sich einem überfachlichen theatralen Ansatz in der Lehrendenbildung widmet, im Folgenden mehr Beachtung geschenkt werden. Köhler bezieht sich für ihre Argumentation auf das Konzept des professionellen Habitus und erarbeitet einen Komplex von „professionellen pädagogischen Kompetenzen“ (S. 112), die jede Lehrperson aufweisen sollte. Bezugnehmend auf das Konzept der Entwicklung von Professionalität im Internationalen Kontext (EPIK) nennt sie die folgenden Kompetenzen als „Handlungsbereiche, in denen sowohl Fähigkeiten und Fertigkeiten als auch Haltungen zur Geltung kommen“ (S. 113): Professionsbewusstsein, Reflexions- und Diskursfähigkeit, Differenzfähigkeit, Kooperation und Kollegialität sowie Personal Mastery.

Dies deutet implizit auf das Verständnis von Lehre als Handwerk², denn so wie jegliches Handwerk ist Lehre verkörpert und hängt von einem hohen Grad an verkörperten Gewohnheiten ab. (Lehrende müssen beispielsweise, so wie Schauspielende, dazu trainiert werden, die Dimensionen und die spezifischen Eigenschaften des physischen Raumes, in dem sie arbeiten, zu fühlen oder intuitiv und in Echtzeit subtile Veränderungen der Aufmerksamkeit im Raum wahrzunehmen.) Die Verhaltensweisen, die Köhler anspricht, können akkurater beschrieben werden als Grundeinstellungen des Geistes - oder als das, was wir unter der ethischen Dimension des Lehrens verstehen. Diese Einstellungen und Verhaltensweisen sind, wie Köhler hervorhebt, nicht nur trainierbar, sondern müssen trainiert werden, und zwar lang vor dem ersten Unterricht.

Köhler zeigt in weiterer Folge auf, dass ein explizit theatrales (im Sinne von performatives) Training im Rahmen der Lehrendenbildung einen effektiven Rahmen bietet, diese fünf Kompetenzen zu behandeln und deshalb, so Köhler, von Anfang an in die Lehrendenbildung eingebettet werden sollten:

Die Integration theaterpädagogischer Elemente in die Grundausbildung des Lehramtstudiums und die damit verbundenen Konsequenzen für den Zugang zur pädagogischen Professionalität, eine Veränderung des eigenen Bildes über den Beruf, der didaktischen Grundauffassungen und eine

\footnotetext{
${ }^{2}$ Weitere Überlegungen zum Verständnis von der Lehre als Handwerk in Crutchfield (2019).
} 
Erweiterung des methodischen Repertoires in allen Unterrichtsfächern sind erstrebenswert. (S. 202-203)

Stellen wir uns also vor, dass Julia Köhler - eine ausgebildete Theaterkünstlerin und erfahrene Lehrerin - ein theatrales Curriculum für Lehramtsstudierende designt und umsetzt: Wie würde solch ein Curriculum aussehen? Auch hier bietet Köhler eine überzeugende Antwort. Bezugnehmend auf die Arbeit der Bundesarbeitsgemeinschaft „Theater in der Schule“ schlägt Köhler ein Modell vor, dass Lehrveranstaltungen zu Themen wie "Theaterpädagogik zur Entwicklung der Lehrer/innenpersönlichkeit” "Theaterpädagogik in verschiedenen Lernsituationen” und „Theaterpädagogik und Fachunterricht” anbietet.

Bei näherer Betrachtung dieses Vorschlags wird klar, dass Köhlers Verständnis von Theaterpädagogik starke Ähnlichkeiten zu dem hat, was im Kontext dieser Zeitschrift als performative Pädagogik verstanden wird. Durch den theoretischen Bezug auf die Theaterwissenschaft einerseits und Erziehungswissenschaft andererseits erarbeitet sie ein überzeugendes Plädoyer zur Fundierung einer performativen Lehr- und Lernkultur.

Das ist allerdings kaum überraschend. Wenn sich der performative Ansatz in der Bildung von den performativen Künsten inspirieren lässt, ist es durchaus sinnvoll, dass sich Lehrende nicht nur mit den Aussagen der Künstler:innen über ihre Kunst auseinandersetzen, sondern auch damit, was die Theoretiker:innen dazu sagen. Denn schließlich sind Praxis, Theorie und Forschung, wie diese Zeitschrift selbst reichlich belegt, unzertrennlich: Jede Praxis impliziert eine Theorie, die die Forschung leitet, und diese hat wiederum Einfluss auf die Praxis. Obwohl die theoretischen Arbeiten von Theaterwissenschaflter:innen wie beispielsweise Erika Fischer-Lichte oder Andreas Kotte in ihrer Haarspalterei rund um Konzepte manchmal kantisch wirken, so sollte es uns auch ein Anliegen sein, über unseren eigenen Tellerrand zu blicken und zu hören, was anderswo am Tische gesagt, gedacht und diskutiert wird. Die Terminologie mag zwar manchmal verwirrend sein, aber wir werden doch immer wieder feststellen - und so geht es dem Rezensenten im Falle von Julia Köhlers Buch -, dass die Einsichten hilfreich und (noch viel wichtiger) ermutigend sind.

\section{Bibliografie}

Crutchfield, J. (2019). The Teaching Lab: An immodest proposal. In S. Even, D. Miladinović \& B. Schmenk (Hrsg.), Lernbewegungen inszenieren: Performative Zugänge in der Sprach-, Literaturund Kulturdidaktik. Festschrift für Manfred Schewe zum 65. Geburtstag (S. 33-43). Narr Francke Attempto. 
Crutchfield: Rezension von Theatrale Wege in der Lehrer/innenbildung

Fleiner, M. (2016). Performancekünste im Hochschulstudium: Transversale Sprach-, Literatur- und Kulturerfahrungen in der fremdsprachlichen Lehrerbildung (Edition SCENARIO Vol. II). SchibriVerlag.

Schewe, M. (2013). Taking stock and looking ahead: Drama pedagogy as a gateway to a performative teaching and learning culture. Scenario, 7(1), 5-23. https://doi.org/10.33178/scenario.7.1.2

Vaßen, F. (2016). Die Diversität von Theaterpädagogik in der Schule - Theater und theatrale Ausbildung im Kontext des Lehrverhaltens, als Unterrichtsmethode und als künstlerischästhetisches Fach. In S. Even \& M. Schewe (Hrsg.), Performatives Lehren, Lernen, Forschen.

Performative Teaching, Learning, Research (Edition SCENARIO Vol. III, S. 87-125). Schibri-Verlag. 